\title{
Susceptibility of Atlantic cod Gadus morhua, halibut Hippoglossus hippoglossus and wrasse (Labridae) to Aeromonas salmonicida subsp. salmonicida and the possibility of transmission of furunculosis from farmed salmon Salmo salar to marine fish
}

\author{
Brit Hjeltnes $^{1, *}$, Øivind Bergh ${ }^{2}$, Heidrun Wergeland ${ }^{3}$, Jens Chr. Holm ${ }^{2}$ \\ ${ }^{1}$ Institute of Marine Research, Department of Aquaculture, PO Box 1870, N-5024 Bergen, Norway \\ ${ }^{2}$ Institute of Marine Research, Austevoll Aquaculture Research Station, N-5392 Storebo, Norway \\ ${ }^{3}$ Department of Fisheries and Marine Biology, University of Bergen, HIB, N-5020 Bergen, Norway
}

\begin{abstract}
The possibility of transmission of Aeromonas salmonicida subsp. salmonicida from Atlantic salmon Salmo salar to cod Gadus morhua, halibut Hippoglossus hippoglossus, and wrasse (Labridae) was studied in both laboratory cohabitation and injection challenge trials, and in a field situation during an outbreak of furunculosis in Atlantic salmon in 2 sea farms containing both cod and salmon. A. salmonicida subsp. salmonicida was isolated from cod, halibut and wrasse, but only occasionally. The injection challenge studies with $A$. salmonicida subsp. salmonicida were carried out on cod and halibut. Despite challenge with $4.6 \times 10^{3}, 4.6 \times 10^{4}$ and $4.6 \times 10^{5} \mathrm{CFU}$ (colony-forming units) of the bacterium, only 1 halibut died, whereas no mortality occurred in the cod groups. In cohabitation challenge trials in which cod, halibut and wrasse were kept together with infected salmon, 1 cod and 1 halibut died, with subsequent isolation of $A$. salmonicida subsp. salmonicida from their kidneys. In a group of salmon challenged in the same way with infected salmon cohabitants, all the salmon died. In the field study, there were high mortalities of salmon due to furunculosis. However, A. salmonicida subsp. salmonicida was isolated from only 1 of the wrasse used as 'cleaner fish' for the salmon. $A$. salmonicida was not isolated from cod during the field study. The results suggest that $A$. salmonicida subsp. salmonicida can be transmitted from salmon and cause disease in cod, halibut and wrasse, but that this is a relatively rare event.
\end{abstract}

KEY WORDS: Aeromonas salmonicida Marine fish Transmission

\section{INTRODUCTION}

Aeromonas salmonicida subsp. salmonicida, the causative agent of furunculosis, was introduced to one of the main fish farming districts in Norway in 1985 by importation of infected Atlantic salmon Salmo salar smolts from Scotland (Egidius 1987). The bacterium soon spread and it has now been detected in farmed Atlantic salmon along almost the entire coastal fish farming area

•E-mail: brit@imr.no of Norway. Furthermore, furunculosis has been transmitted to wild Atlantic salmon in several rivers.

During outbreaks of furunculosis, infected fish probably release high numbers of Aeromonas salmonicida subsp. salmonicida (Enger et al. 1992). The bacterium is difficult to isolate from environmental sources but can be detected by other means. Estimation by immunofluorescence microscopy using monoclonal antibodies showed approximately $10^{4}$ cells $\mathrm{ml}^{-1}$ in the water surface layer, $10^{2}$ cells $\mathrm{ml}^{-1}$ in the water column within an affected salmon farm and $10^{6}$ cells $\mathrm{ml}^{-1}$ in the sediment immediately beneath the farm. Further- 
more, A. salmonicida subsp. salmonicida was detected in small numbers in the water column $1000 \mathrm{~m}$ downstream of the farm (Enger \& Thorsen 1992), and $A$. salmonicida subsp. salmonicida has also been isolated from marine plankton (Nese \& Enger 1993). It is therefore likely that marine fish in the vicinity of fish farms are exposed to the bacterium. However, the possible effects on marine fish due to such an exposure are unknown.

Aeromonas salmonicida has been isolated from a large variety of salmonids and other freshwater and marine fish. Atypical A. salmonicida has been isolated from a number of marine fish species, such as sable fish Anoplopoma fimbria (Evelyn 1971), Atlantic cod (Cornick et al. 1984), marine sand eel Ammodytes lancea (Dalsgaard \& Paulsen 1986), Pacific herring Clupea harengus pallasi (Traxler \& Bell 1989), flounder Platichthys flesus (Wiklund \& Bylund 1991), goldsinny (Frerichs et al. 1992) and turbot Scophthalmus maximus (Pedersen et al. 1994). Typical A. salmonicida (subsp. salmonicida) has been isolated from Atlantic cod, coalfish Pollachius virens (Willumsen 1990), turbot (Nougayrede et al. 1990, Toranzo \& Barja 1992), and goldsinny, rockcook and cuckoo wrasse Labrus bimaculatus (Treasurer \& Cox 1991). In turbot, the isolation of typical A. salmonicida was associated with daily mortalities of between 2.5 and $3 \%$ and pathological findings such as congestive hemorrhagic erosion of the fins and occasionally congested livers, kidneys, ascites and gastric ulcers (Nougayrede et al. 1990, Toranzo \& Barja 1992). In cod and coalfish there is no such documentation of disease as typical $A$. salmonicida was isolated from the gills and intestine of apparently healthy fish caught in the vicinity of net pens containing Atlantic salmon suffering from furunculosis (Willumsen 1990). In all cases of infection of the marine fish species with typical A. salmonicida, the source of infection was very likely farmed salmonids.

This study was undertaken to examine the possibility of transmission of Aeromonas salmonicida subsp. salmonicida from Atlantic salmon to marine fish such as Atlantic cod Gadus morhua, halibut Hippoglossus hippoglossus and wrasse (family Labridae) and to study the susceptibility of these species to the bacterium.

\section{MATERIALS AND METHODS}

Field study. The field study was carried out in June-October 1991 at the Institute of Marine Research, Austevoll Aquaculture Research Station, situated on the island Huftarøy south of Bergen on the west coast of Norway. The research station has 2 sea cage sites, $A$ and $B$, each with populations of both Atlantic salmon and Atlantic cod. The 2 sites are approximately $300 \mathrm{~m}$ apart. Site $\mathrm{A}$ is well protected. shallow (depth $15 \mathrm{~m}$ ), and has low water exchange. Site B is more exposed, deeper (depth $50 \mathrm{~m}$ ), and has good water exchange. The salmon and the cod were kept in separate cages approximately $1 \mathrm{~m}$ apart. Wrasse were used to free salmon of the salmon louse Lepeophtheirus salmonis and were present in all of the salmon cages. The species of wrasse used were goldsinny Ctenolabrus rupestris, rockcook Centrolabrus exoletus and corkwing Symphodus melops. At the beginning of the study, there were 9700 salmon (mean weight $1000 \mathrm{~g}$ ) and $7800 \mathrm{cod}$ (mean weight $1100 \mathrm{~g})$ at Site $\mathrm{A}$. These fish were brought in during 1990. At Site $B$, there were 18000 salmon smolts (60 g) transferred to this site at the beginning of June. In midAugust, $12000 \mathrm{cod}(100 \mathrm{~g})$ were brought in to this site. The salmon were vaccinated against cold water vibriosis (Vibrio salmonicida) and the cod were vaccinated against vibriosis (Vibrio anguillarum). In October 1990, Aeromonas salmonicida subsp. salmonicida was isolated from salmon at both sites. This was the first time the bacterium was isolated at these sites and the isolation was associated with low mortalities. During 1990, salmon lice were frequently observed on the salmon. Health and treatment data for the fish brought into the sites in 1991 were lacking. Water temperature peaked over a period of several weeks in summer (see Fig. 1A).

At both sites, dead fish were removed daily and cultured for bacteria. When high mortality occurred in the salmon populations, random samples of the dead fish were collected for bacterial cultivation.

To enhance the exposure of wrasse to Aeromonas salmonicida subsp. salmonicida, 11 goldsinny, 3 rockcook and 4 corkwings were placed in a cage with salmon suffering from a massive outbreak of furunculosis. After $3 \mathrm{wk}$, none of the wrasse had died; they were collected, examined for gross pathological changes, and cultured for bacteria.

Laboratory cohabitation trial. Atlantic salmon (mean weight \pm SD: $218 \pm 27 \mathrm{~g}$ ), Atlantic halibut (mean weight $180 \pm 45 \mathrm{~g}$ ). Atlantic cod (mean weight $208 \pm$ $42 \mathrm{~g}$ ) and wrasse (mean weight $133 \pm 35 \mathrm{~g}$ ) were used in a cohabitation challenge trial with a Norwegian isolate of Aeromonas salmonicida subsp. salmonicida (As 55 Matre) as the challenge organism. The bacterium was isolated from Atlantic salmon at the Institute of Marine Research, Matre Aquaculture Research Station, situated at Matredal, north of Bergen. The bacterium was grown on Tryptone Soya Agar (TSA-agar) (Oxoid, Unipath Ltd, Hampshire, UK) and incubated aerobically at $20^{\circ} \mathrm{C}$ for $48 \mathrm{~h}$. The bacterium was washed with $0.9 \% \mathrm{NaCl}$ and resuspended in $0.9 \%$ $\mathrm{NaCl}$ before it was used as inoculum.

The fish were kept in 400 l tanks supplied with UVtreated seawater with a salinity of $34 \%$ at 10 to $12^{\circ} \mathrm{C}$. 
During the experiment, cod, salmon and halibut were fed commercially available dry pellets. The wrasse were fed frozen krill (Thysanoessa sp.) from the Barent Sea. Twenty-five fish of each species (for wrasse it was actually 21 goldsinny and 4 rockcook) were placed in separate tanks and exposed to Aeromonas salmonicida subsp. salmonicida by cohabitation challenge. Atlantic salmon injected (i.p.) with $0.2 \mathrm{ml}$ of $0.9 \% \mathrm{NaCl}$ containing $2 \times 10^{3} \mathrm{CFU}$ (colony-forming units) were used as cohabitants and 5 injected individuals were added to each group of $25 \mathrm{fish}$. At 10 wk post-challenge, 20 unchallenged salmon, marked by fin clipping (adipose fin), were placed in each fish tank. A latent carrier test (Røttereng et al. 1989) adopted from Bullock \& Stuckey (1975) was performed on all surviving fish at 15 wk post-challenge. Briefly, the fish were injected i.p. with $20 \mathrm{mg}$ prednisolone acetate $\left(10 \mathrm{mg} \mathrm{ml}^{-1}\right.$, Hoechst, Frankfurt, Germany) $\mathrm{kg}^{-1}$ fish. During the experiment, dead fish were removed daily and inspected for gross pathological changes. Kidney samples were taken for bacteriological cultivation. The experiment was terminated at 20 wk post-challenge. Survivors were euthanized, examined for gross pathological changes and kidney samples were cultured for bacteria. Gill samples from all surviving salmon and samples of gills, heart, liver and gut were taken from 5 fish in each group of halibut, cod and wrasse and processed for histological examination.

Laboratory injection trial. Separate injection trials with Atlantic halibut and Atlantic cod were carried out. The fish were kept in $400 \mathrm{l}$ tanks supplied with UVtreated seawater with a salinity of $34 \%$ at 10 to $12^{\circ} \mathrm{C}$. In the first injection trial 3 groups of 4 halibut (mean weight $\pm \mathrm{SD}: 392 \pm 122 \mathrm{~g}$ ) were kept in separate tanks and injected i.p. with $3.0 \times 10^{2}, 3.0 \times 10^{3}$ or $3.0 \times 10^{4} \mathrm{CFU}$ (As 55 Matre) in $0.2 \mathrm{ml}$ of $0.9 \% \mathrm{NaCl}$. The fish were observed for $11 \mathrm{wk}$. In the second injection trial 3 groups of $5 \mathrm{cod}$ (950 g), tagged with Floy Anchor Tags ${ }^{\text {TM }}$ (Floy Tag and Manufacturing, Inc., Seattle, WA, USA), were injected i.p with $4.6 \times 10^{3}, 4.6 \times 10^{4}$ or $4.6 \times 10^{5} \mathrm{CFU}$ in $0.2 \mathrm{ml} 0.9 \%$ $\mathrm{NaCl}$. These fish were kept together in 1 tank. The fish were observed for $10 \mathrm{wk}$. On termination of the experiments, all fish were examined for pathological changes. Kidney samples were cultured for bacteria, and samples from gill, heart, liver, spleen and gut were collected for histological processing.
Bacteriology. Kidney samples were inoculated on TSA-agar and TSA-agar supplemented with $2 \% \mathrm{NaCl}$. The agar plates were incubated aerobically at $20^{\circ} \mathrm{C}$ for $4 \mathrm{~d}$. Colonies producing a brown diffusable pigment were tested by agglutination with a specific antiserum, Mono-As (BioNor Aqua, Skien, Norway) against Aeromonas salmonicida and checked for autoagglutination and motility. API 20E and A.PI 50CH (Bio Mérieux, Marcy l'Etoile, France) were used for biochemical characterisation of isolates that were pigment producing, Gram-negative, non-motile, autoagglutinating coccoid rods and that were positive in the Mono-As serological test. The type strain NCMB 1102 and 2 Norwegian isolates, As 55 Matre (used in the laboratory challenge test) and FT 449 of Aeromonas salmonicida subsp. salmonicida, were included as standards.

Colonies growing on agar, supplemented with $2 \%$ $\mathrm{NaCl}$, which did not produce brown pigment were tested for sensitivity to the Vibriostat agent $0 / 129$ (BDH, London, UK). Sensitive colonies were considered to be Vibrio sp. This conclusion was confirmed by growth on Tryptone Citrate Bile Salt (TCBS) agar or by a positive agglutination test (Mono-Va, BioNor 
Aqua). No further characterization was carried out on the non Aeromonas salmonicida and non Vibrio sp. isolates.

SDS-PAGE. SDS-PAGE resolution of proteins from bacterial isolates was performed according to the method of Laemmli (1970) with minor modifications as described by Tsang et al. (1983). All gels contained $12.5 \%$ acrylamide. Samples of the freeze-dried bacterial isolates $(4 \mu \mathrm{g})$ were separated on a Mini Protean II xi slab cell (Bio-Rad). Electrophoresis was carried out for $1 \mathrm{~h}$ at $200 \mathrm{~V}$. Separated proteins were silver stained as described by Switzer et al. (1979) and the lipopolysacharide (LPS) was stained according to Tsai \& Frasch (1982).

Western blot. The bacterial isolates were fractionated by SDS-PAGE on a Mini Protean cell as previously described. Antigen ( $4 \mu \mathrm{g}$ ) was loaded into each well. The electrophoresed antigen was transferred to a nitrocellulose membrane (Towbin et al. 1979) using $100 \mathrm{~V}$ for $2 \mathrm{~h}$. After the transfer, the membrane was blocked with a $3 \%$ solution of skimmed milk powder for $16 \mathrm{~h}$ at $4^{\circ} \mathrm{C}$. Immunodetection of proteins and LPS was performed using a Mini Trans-Blot cell (Bio-Rad). Rabbit antiserum against Aeromonas salmonicida subsp. salmonicida, strain FT 499, was diluted at 1:100 before incubation for $2 \mathrm{~h}$ at $20^{\circ} \mathrm{C}$. Bound antibodies were detected by peroxidase goat anti-rabbit immunoglobulin (Bio-Rad) diluted 1:3000 and incubated for $2 \mathrm{~h}$ at $20^{\circ} \mathrm{C}$. The immunoreactive bands were visualised after incubation with Hrp colour development reagent (Bio-Rad) solution for $30 \mathrm{~min}$.

Antiserum. Rabbit antiserum to Aeromonas salmonicida FT 499 was produced by using a vaccine of formalin-treated (0.5) bacteria with optical density (OD) of 0.2 at $620 \mathrm{~nm}$. The bacterial suspension was emulsified in an equal volume of Freund's complete adjuvant and $0.2 \mathrm{ml}$ of the emulsion was injected intramuscularly. The vaccination was repeated 1 wk later using $0.4 \mathrm{ml}$ and this was followed by 2 subcutaneous injections, 14 and $30 \mathrm{~d}$ later, of 0.8 and $0.3 \mathrm{ml}$, respectively. Serum was sampled $10 \mathrm{~d}$ after the last infection and stored in aliquots at $-80^{\circ} \mathrm{C}$.

\section{RESULTS}

\section{Field study}

During the experimental period, mortalities were high in the salmon populations at both sea cage sites (Fig. 1B). Aeromonas salmonicida subsp. salmonicida was isolated from 79 and $49 \%$ of the fish mortalities sampled at Sites A and B, respectively (Fig. 2). Salmon lice were observed on several fish. In the cod populations the mortalities were relatively low except for a mortality peak in the beginning of Week 34 (Fig. 1B). Bacterial cultivation from kidney tissue was performed on a total of $30 \mathrm{cod}$ and heavy growth of Vibrio sp. was isolated from 5 fish. In 14 fish, a slight to moderate growth of a mixed bacterial flora was seen, whereas in $11 \mathrm{fish}$, there was no bacterial growth. A. salmonicida subsp. salmonicida was not isolated from any of the dead cod (Fig. 2). In the wrasse populations, used to free salmon of sea lice in the salmon cages, 2 corkwings died during the observation period. From one of these fish, heavy growth of $A$. salmonicida subsp. salmonicida was isolated in
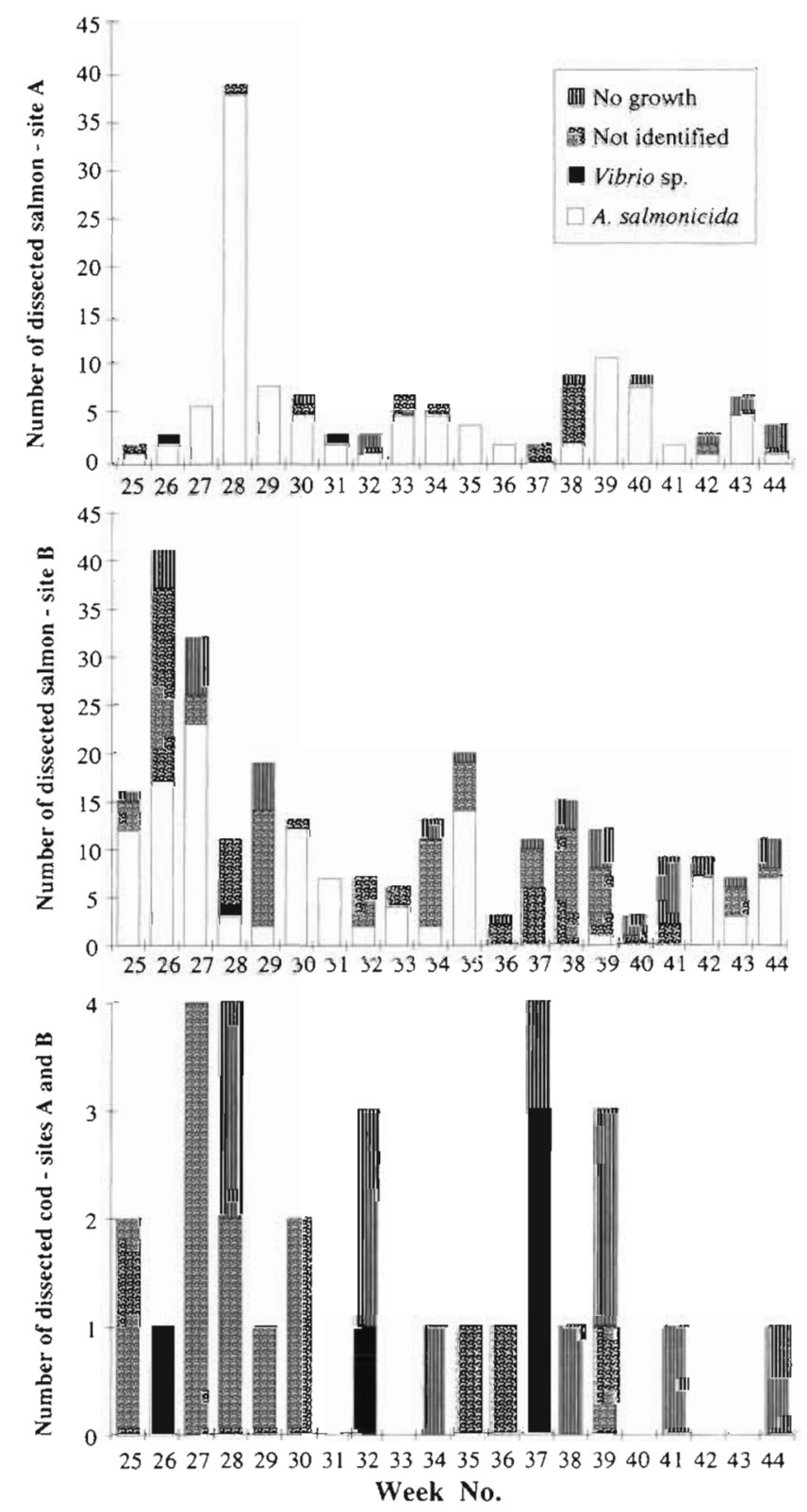

Fig. 2. Bacterial cultivation results for dissected salmon mortalities from Site A and from Site B, and dissected cod mortalities from Sites A and B 
pure culture. No bacteria were isolated from the other fish. Furthermore, no wrasse died as a result of the enhanced exposure to salmon suffering from a massive outbreak of furunculosis, and $A$. salmonicida subsp. salmonicida was not isolated from any of the euthanized wrasse from the enhanced exposure trial.

\section{Laboratory cohabitation challenge trial}

The i.p.-infected salmon used in the cohabitation experiments stopped feeding shortly after challenge by injection. They became lethargic and started to die. By $10 \mathrm{~d}$ post-injection, 19 of 20 of these infected salmon were dead and the remaining infected specimen (in the tank with the non-injected salmon) died after $8 \mathrm{wk}$. In the non-injected salmon group, furunculosis was diagnosed $19 \mathrm{~d}$ post-challenge, and mortality reached $50 \%$ after 8 wk and $100 \%$ after 16 wk (Fig. 3). Aeromonas salmonicida subsp. salmonicida was isolated from all of the injected and non-injected salmon cohabitants. In the other cohabitant challenge groups, 1 halibut and 1 cod died after 6 and 8 wk, respectively. Pure cultures of $A$. salmonicida subsp. salmonicida were isolated from both fish. Of the wrasse, 1 died after

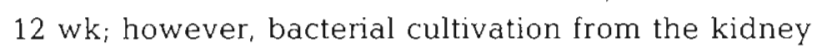
gave negative results.

The latent carrier test (LCT) resulted in an $80 \%$ mortality within $20 \mathrm{~d}$ among the healthy salmon introduced to the cohabitant challenge salmon group at $10 \mathrm{wk}$ post-challenge and tested at $15 \mathrm{wk}$ post-challenge. Aeromonas salmonicida subsp. salmonicida was isolated from all but 1 fish.

In a similar test (LCT) performed on the cod group, the fish became extremely stressed by the added handling necessitated by the test. This resulted in oxygen depletion in the water supply. Because the water flow was not increased to compensate for this negative effect, $9 \mathrm{cod}$ and 5 of the freshly introduced salmon died within $18 \mathrm{~h}$ after injection of the prednisolone acetate used in the LCT. The remaining cod never recovered completely. They fed poorly, appeared lethargic, and many were dark and exophthalmic. Two cod had to be killed before terminating the experiment at 16 wk post-challenge. Vibrio sp. and unclassified streptococci were isolated from the dead and moribund cod and from some of the surviving fish. Aeromonas salmonicida subsp. salmonicida was not isolated from either the cod or the freshly introduced salmon in this group.
In the wrasse and halibut groups, no mortalities occurred following the LCT. This also held true for the salmon freshly introduced to the wrasse and halibut tanks and given the LCT. Bacterial cultivation from the survivors gave negative results.

No bacterial microcolonies or other pathological findings were recorded by histological examinations of surviving salmon, halibut or wrasse. In one of the surviving cod, a cyst-like structure of unknown etiology was observed on the gills. The other cod appeared normal.

\section{Laboratory injection challenge trial}

In the halibut injection trial, only 1 halibut died. The dead fish had been injected with $3 \times 10^{2} \mathrm{CFU}$; it died 5 d post-injection and Aeromonas salmonicida subsp. salmonicida was isolated in pure culture from the kidney. None of the challenged fish in the cod group died and no bacteria were isolated from the kidneys taken from the euthanized halibut and cod at the end of the experiments.

\section{Bacteriology}

The biochemical characteristics of the Aeromonas salmonicida subsp. salmonicida isolates from the wrasse and the salmon in the field study, the cod and the salmon in the laboratory cohabitation trial, and the isolate from halibut in the injection trial were similar to the challenge strains (As 55 Matre) and the reference 
strains NCMB 1102 and FT 449. The halibut isolate from the cohabitant trial was weakly positive in the lysine test. The protein and LPS profiles of all of the strains tested on SDS-PAGE revealed the same bands except for strain 1102 NCMB which lacked a protein band corresponding to the A-layer (data not shown). With exception of $1102 \mathrm{NCMB}$, all isolates showed the same immunoreactive bands (data not shown).

\section{DISCUSSION}

In the cohabitation challenge trial, we demonstrated only very limited transmission of Aeromonas salmonicida subsp. salmonicida from infected Atlantic salmon to cod and halibut, but the isolation of heavy growth of this bacterium in pure culture from the kidneys of the 1 cod and 1 halibut that died indicated that they died from furunculosis. As demonstrated by the injection challenge trial, neither cod nor halibut are normally very susceptible to infections by $A$. salmonicida subsp. salmonicida. Both cod and halibut survived injections with high amounts of bacteria that readily killed Atlantic salmon of the same size. In the cod and halibut injection trial, the only fish to die was the smallest halibut which also happened to be the one that had been exposed to some extra handling stress during the injection (it was temporarily lost on the floor after injection).

The results from the cohabitation challenge trial are consistent with the observations obtained from the field study. Due to the massive outbreaks of furunculosis in the salmon populations, the farmed cod received a severe exposure to Aeromonas salmonicida subsp. salmonicida. Furthermore, the cod were reared under stressful conditions with high water temperatures rendering them more susceptible to bacterial infections. Yet, no A. salmonicida subsp. salmonicida was isolated from dead and moribund cod during the observation period. The differences in mortalities between Sites $A$ and $B$ probably reflected the diffences in the environmental conditions at the 2 sites. In the shallow site (A) some of the mortalities may have been associated with a lack of adequate oxygen in the water. It seems reasonable to conclude that although $A$. salmonicida subsp. salmonicida can be transmitted to cod and halibut and occasionally cause disease, the bacterium does not pose any significant threat to adult fish under normal 'grow-out' conditions. Further studies on fry and larvae need to be carried out before a conclusion on the susceptibility of the early life stages of cod and halibut to $A$. salmonicida subsp. salmonicida can be reached.

The isolation of Aeromonas salmonicida subsp. salmonicida from various healthy-appearing marine fish, including cod (Willumsen 1990), suggests that such fish may become carriers of the bacterium. In fact, however, our results do not support this. None of the $A$. salmonicida-exposed cod, halibut or wrasse in our trials proved positive for the bacterium following the LCT 15 wk after initial exposure. Furthermore, healthy but susceptible salmon, made to associate with the $A$. salmonicida-exposed cod, halibut and wrasse some 10 wk after the initial exposure of these 3 marine species to the pathogen, failed to contract $A$. salmonicida infections as judged by the results of the LCT conducted on the salmon. In contrast, when the healthy salmon were forced to associate with salmon initially exposed to $A$. salmonicida some $10 \mathrm{wk}$ earlier, they contracted the infection as determined by the LTC. Our failure to culture the pathogen from exposed cod, halibut and wrasse may, admittedly, have been due to the fact that only kidney tissues were sampled. There are, for example, reports that the bacterium, in the carrier state, may occur in locations other than the kidney: the gills (Bruno 1986, McArdle et al. 1986), the intestine (Willumsen 1990, Hiney et al. 1994), or the skin mucus (Cipriano et al. 1992). If so, it seems even more likely that the A. salmonicida-exposed cod, halibut and wrasse should have been infective for the susceptible healthy salmon forced to associate with them. The fact that this was not the case reinforces the conclusion that the cod, halibut and wrasse did not become carriers of A. salmonicida subsp. salmonicida.

We conclude that Aeromonas salmonicida subsp salmonicida is not highly pathogenic for adult-size cod halibut and wrasse, and that under normal fish farm conditions they are not likely to contract the bacterium, develop furunculosis, or become long-term carriers of the pathogen. Reports of the bacterium causing furunculosis in wrasse (Collins et al. 1991, Treasurer \& Cox 1991, Treasurer \& Laidler 1994) probably reflected the outcome of an exceptional set of field circumstances where the wrasse were constantly forced to associate with, and eat, salmon dead and dying of furunculosis apparently because their normal source of food was at the time in short supply. Treasurer \& Laidler (1994), after all, failed to cause furunculosis in wrasse in the laboratory using a waterborne challenge that proved highly lethal for salmon. Also, the presence of the bacterium in healthy cod and coalfish near a furunculosis-affected salmon farm (Willumsen 1990) may have represented recent and non-persistent infections. The positive samples were apparently obtained during a short-term study.

In summary, although it is clear that Aeromonas salmonicida subsp. salmonicida can kill marine fish and perhaps even be carried by such fish, these situations in mature cod, halibut and wrasse are likely to be rare events stemming from unusual conditions. We conclude that such events represent the exception rather than the rule. 
Acknowledgements. The authors thank Kari Andersen, Randi Birkeland, Hari Rudra and Ingrid Uglenes for skilful technical assistance. This study was financed by the Norwegian Research Council (NFFR 1203-703.433 and NFFR 1401701.358).

\section{LITERATURE CITED}

Bruno DW (1986) Furunculosis in sea-reared Atlantic salmon, Salmo salar L. Colonization of the gill epithelium. Bull Eur Ass Fish Pathol 6:76

Bullock GL, Stuckey HM (1975) Aeromonas salmonicida, detection of asymptomatically infected trout. Prog FishCult 37:237-239

Cipriano RC, Ford LA, Teska JD, Hale EH (1992) Detection of Aeromonas salmonicida in the mucus of salmonid fish $J$ aquat Anim Health 4:114-118

Collins RO, Ferguson DA, Bonniwell MA (1991) Furunculosis in wrasse. Vet Rec 128:43

Cornick JW, Morrison CM, Zwicker B, Shum G (1984) Atypical Aeromonas salmonicida infections in Atlantic cod, Gadus morhua L. J Fish Dis 7:495-499

Dalsgaard I, Paulsen H (1986) Atypical Aeromonas salmonicida isolated from diseased sand-eels, Ammodytes lancea (Cuvier) and Hyperoplus lanceolatus (Lesauvege). J Fish Dis 9:361-364

Egidius E (1987) Import of furunculosis to Norway with Atlantic salmon smolts from Scotland. Comm Meet int Coun Explor Sea CM-ICES/F:8

Enger $\varnothing$, Gunnlaugsdottir B, Thorsen BK, Hjeltnes B (1992) Infectious load of Aeromonas salmonicida subsp. salmonicida during the initial phase of a cohabitant infection experiment with Atlantic salmon, Salmo salar. J Fish Dis 15:425-430

Enger $\varnothing$. Thorsen BK (1992) Possible ecological implications of the high cell surface hydrophobicity of the fish pathogen Aeromonas salmonicida. Can J Microbiol 38 . $1048-1052$

Evelyn TPT (1971) An aberrant strain of the bacterial fish pathogen Aeromonas salmonicida isolated from a marine host, the sablefish (Anoplopoma fimbria), and from two species of cultured Pacific salmon. J Fish Res Bd Can 28: $1629-1634$

Frerichs GN, Millar SD, McManus C (1992) Atypical Aeromonas salmonicida isolated from healthy wrasse (Ctenolabrus rupestris). Bull Eur Ass Fish Pathol 12:48-49

Hiney MP, Kilmartin JJ, Smith PR (1994) Detection of Aeromonas salmonicida in Atlantic salmon with asymptomatic furunculosis infections. Dis aquat Org 19:161-167

Laemmli UK (1970) Cleavage of structural proteins during the assembly of the head of bacteriophage T4. Nature 227: $680-685$

McArdle JF, Dooley-Martyn C, McKiernan F (1986) Histological examination of the gills as a method of detecting

Responsible Subject Editor: T. P. T. Evelyn, Nanaimo,

B.C. Canada asymptomatic carriers of $A$. salmonicida in Atlantic salmon (Salmo salar). Bull Eur Ass Fish Pathol 6:80-84

Nese L, Enger $\varnothing$ (1993) Isolation of Aeromonas salmonicida from salmon lice Lepeophtheirus salmonis and marine plankton. Dis aquat Org 16:79-81

Nougayrede P, Sochon E, Vuillaume A (1990) Isolation of Aeromonas subspecies salmonicida in farmed turbot (Psetta maxima) in France. Bull Eur Ass Fish Pathol 10 $139-140$

Pedersen K, Kofod H, Dalsgaard I, Larsen JL (1994) Isolation of oxidase-negative Aeromonas salmonicida from diseased turbot Scophthalmus maximus. Dis aquat Org 18: $149-154$

Røttereng PJ, Silset TO, Arnesen CE (1989) Latent carrier test - nyttig hjelpemiddel for å påvise skjulte smittebærere i fiskeoppdrettsanlegg. Norsk Veterinærtidsskrift 101 $439-440$

Switzer RC III, Merril CR, Shifrin S (1979) A highly sensitive silver stain for detecting proteins and peptides in polyacrylamide gels. Analyt Biochem 98:231-237

Toranzo AE, Barja JL (1992) First report of furunculosis in turbot reared in floating cages in northwest of Spain. Bull Eur Ass Fish Pathol 12:147-149

Towbin H, Staehelin T, Gordon J (1979) Electrophoretic transfer of proteins from polyacrylamide gels to nitrocellulose sheets: procedure and some applications. Proc Natl Acad Sci USA 76:4350-4354

Traxler GS, Bell GR (1989) Pathogens associated with impounded Pacific herring Clupea harengus pallasi, with emphasis on viral erythrocytic necrosis (VEN) and atypical Aeromonas salmonicida. Dis aquat Org 5:93-100

Treasurer J, Cox D (1991) The occurrence of Aeromonas salmonicida in wrasse (Labridae) and the implication for Atlantic salmon farming. Bull Eur Ass Fish Pathol 11 $208-210$

Treasurer JW, Laidler LA (1994) Aeromonas salmonicida infection in wrasse (Labridae), used as cleaner fish, on an Atlantic salmon, Salmo salar L., farm. J Fish Dis 17: $155-161$

Tsai CM, Frasch CE (1982) A sensitive silver stain for detecting lipopolysaccharide in polyacrylamide gels. Analyt Biochem 119:115-119

Tsang VCW, Peralta JM, Simons AR (1983) Enzyme linked immunoelectrotransfer blot techniques (EITB) for studying the specificities of antigens and antibodies separated by gel electrophoresis. Meth Enzymol 92:377-391

Wiklund T, Bylund G (1991) A cytochrome oxidase negative bacterium (presumptively an atypical Aeromonas salmonicida) isolated from ulcerated flounders (Platichthys flesus, L.) in the northern Baltic Sea. Bull Eur Ass Fish Pathol 11:74-76

Willumsen B (1990) Aeromonas salmonicida subsp. salmonicida isolated from Atlantic cod and coalfish. Bull Eur Ass Fish Pathol 10:62-63

Manuscript first received: May 20, 1994

Revised version accepted: March 23, 1995 